\title{
Effect of Fibroblast Growth Factor Combination with Ethanol Extract of Morinda citrifolia L. on Blood Glucose levels
}

\author{
Dharma $\mathbf{S}^{1, *}$, Rahmawati $\mathbf{Y}^{2}$, Nessa ${ }^{2}$, Dillasamolla $\mathbf{S}^{1}$
}

Dharma $\mathrm{S}^{1, *}$, Rahmawati $\mathrm{Y}^{2}$, Nessa ${ }^{2}$, Dillasamolla $\mathbf{S}^{1}$

'Faculty of Pharmacy, Andalas University, INDONESIA.

2Indonesian Pioneer Pharmacy College,

Padang, INDONESIA.

\section{Correspondence}

\section{Dharma S}

Faculty of Pharmacy, Andalas University, INDONESIA.

E-mail: suryadharma@phar.unand.ic.id

History

- Submission Date: 13-08-2019;

- Review completed: 07-10-2019;

- Accepted Date: 22-10-2019.

DOI : 10.5530/pj.2019.11.238

Article Available online http://www.phcogj.com/v11/i6s

\section{Copyright}

(c) 2019 Phcogj.Com. This is an openaccess article distributed under the terms of the Creative Commons Attribution 4.0 International license.

\begin{abstract}
A research has been conducted on the effect of giving Fibroblast Growth Factor (FGF) with Morinda citrifolia L. ethanol extract. This study aims to determine whether the administration of a combination of FGF with ethanol extract of noni fruit can reduce blood glucose levels in diabetes mice induced by alloxan. FGF requires amino acids in regenerating pancreatic $\beta$ cells, where the amino acids expected from noni fruit can provide a signal response in regenerating pancreatic $\beta$ cells. In addition, the active substances contained in noni fruit namely xeronine and flavonoid alkaloids can function to reduce blood glucose levels. Test animals were divided into 6 groups, each group consisted of 10 male white mice. Group 1 is a normal control group is a group without any given. Group 2 was a negative control group given $150 \mathrm{mg} / \mathrm{kg}$ alloxan. Group 3, 4, and 5 are the treatment groups that are given alloxan and the combination of noni fruit ethanol extract with 3 variations of dose (125; 350; and 1000) mg / KgBW plus FGF dose of $800 \mathrm{mg} / \mathrm{kgBW}$, group 6 is the comparison which is only given FGF alone at a dose of 800 $\mathrm{mg} / \mathrm{kgBW}$. The study was conducted for 21 days, observed every 7th, 14th, 21st day using the Easy Touch ${ }^{\circledR} \mathrm{GCU}$ digital device. The results of this study showed that administration of noni fruit ethanol extract with FGF was able to reduce blood glucose levels by significance $(p<0.05)$ and based on the percentage calculation of blood glucose levels as much as $44.9 \%$ at a dose of $1000 \mathrm{mg} / \mathrm{kgBW}$ on the day observations $21 \mathrm{st}$.

Key words: Diabetes mellitus, FGF, Morinda citrifolia.
\end{abstract}

\section{INTRODUCTION}

Diabetes mellitus (DM) or commonly known as diabetes is a chronic disease. If the pancreas is unable to produce enough insulin, or when the body is unable to use the insulin produced effectively. ${ }^{1}$ Diabetes mellitus is a big threat in human life, because seen from the prevalence of diabetes mellitus estimated at $2.8 \%$ worldwide (171 million people suffer from diabetes mellitus) and is predicted to increase to reach $4.4 \%$ (366 million suffer from diabetes mellitus) in 2030. Diabetes mellitus in Indonesia becomes one of the health problems for the community every year, in 2000 it was reported that in Indonesia there were 8.4 million people with diabetes. This number is predicted to reach 21.3 million and rank fourth in the world after India, China and the United States in $2030 .^{2}$

Although diabetes can now be controlled clinically by using insulin injection, this treatment is not healing and gives discomfort during use and for a long time can cause a number of clinical complications. Treatment with oral insulin and antidiabetic injections does not provide the same degree of control as the function of controlling blood glucose levels by pancreatic $\beta$ cells and cannot prevent adverse consequences as a result of diabetes. ${ }^{3}$

Long-term treatment in controlling blood glucose levels to reach normal conditions requires new methods to improve the function of pancreatic $\beta$ cells as insulin-producing naturally, so as to reduce side effects, uncomfortable use, and diabetes patients dependence on the use of drugs and insulin.

In repairing and reviving tissues and reconnecting neuronal neural networks in the brain, a substance that plays a role in carrying out this task is needed, namely Fibroblast Growth Factor (FGF). FGF is responsible for signal stimulation in the process of early cell development forming a network. ${ }^{4}$

FGF is a group of proteins that have a role to mediate metabolic regulation both autocrine and paracrine. ${ }^{5}$ FGF also has a role that is responsible for signal stimulation in the process of early cell development such as pattern setting, proliferation, differentiation and migration, forming a network. ${ }^{4}$

FGF in regenerating pancreatic $\beta$ cells cannot be alone, FGF requires amino acids, where amino acids expected from noni fruit can help activate signals from FGF which play a role in regenerating pancreatic $\beta$ cells. In noni fruit contains amino acids namely glutamic acid, aspartic acid, isoleucine. ${ }^{6}$ Noni fruit also contains proxeronine, where proxeronine is converted into xeronin in the body by enzymes, this substance can also regenerate damaged pancreatic $\beta$ cells, so that pancreatic $\beta$ cells can function properly again and produce enough insulin to control glucose levels in the blood.

Noni contains a large amount of proxeronin that can be formed into xeronin. Furthermore, it was stated that in the human intestine there is an enzyme proxeronase that can convert proxeronin to xeronin. 
The main function of xeronin in the body is to regulate the form and hardness (rigidity) of specific proteins in cells. If the function of proteins deviates, then the body will experience health problems. ${ }^{8}$ Proxeronine is converted to xeronin alkaloids in the body by an enzyme called proseroninase ${ }^{8}$ Proxeronine forms xeronine which can regenerate damaged pancreatic cells, so that pancreatic beta cells can function properly and produce enough insulin to control blood sugar levels. ${ }^{9}$

\section{MATERIALS AND METHODS}

\section{Plant identification}

Noni fruit plants were identified at Andalas University Herbarium.

\section{Preparation of experimental animals}

The experimental animals used in this experiment were male white mice weighing 20-30 $\mathrm{g}$ and aged 2-3 months. The number of mice used was 60 heads, divided into 6 groups. Each group consisted of 10 mice. One week before the research the mice were acclimatized.

Test animals fasted for 10 hours, before the test animals weighed BB. Checking the initial blood glucose level, 5 groups of test animals were induced with alloxan $150 \mathrm{mg} / \mathrm{kg} \mathrm{BW}$ intra peritoneal, one group was normal control. Mice experiencing hyperglycemic after induction will show an increase in fasting blood glucose levels $>126 \mathrm{mg} / \mathrm{dl}$

Test animals were divided into 6 groups, 5 groups were induced with alloxan and one group without alloxan (normal control).

Table 1 explain about groups of test animal. Group I normal controls: only fed, standardized mice and $0.5 \% \mathrm{Na}$ CMC suspense orally every day during the study.

Group II negative control: given an alloxan $150 \mathrm{mg} / \mathrm{kgBW}$ induction intrapritoneally and CMC $0.5 \%$ orally.

Group III (Dose I): hyperglycemic white mice (alloxan-induced) which were given test preparations of FGF $800 \mathrm{mg} / \mathrm{kg} \mathrm{BW}+$ noni fruit extract $125 \mathrm{mg} / \mathrm{kg}$ BW.

Group IV (Dose II): hyperglycemic white mice (alloxan-induced) given FGF test solution $800 \mathrm{mg} / \mathrm{kg}$ BW + noni fruit extract $350 \mathrm{mg} / \mathrm{kg}$ BW.

Group V (Dose III): hyperglycemic white mice (alloxan-induced) given FGF test solution $800 \mathrm{mg} / \mathrm{kg} \mathrm{BW}+$ extract of noni fruit $1000 \mathrm{mg} / \mathrm{kg}$ BW.

Group VI administration of FGF only: hyperglycemic white mice (alloxan-induced) given $800 \mathrm{mg} / \mathrm{kg}$ BW of FGF solution.

\section{Table 1: Group of animal test.}

\begin{tabular}{|c|c|}
\hline Group & Explanation \\
\hline Group I (normal controls) & $\begin{array}{l}\text { Only fed, standardized mice and } 0.5 \% \mathrm{Na} \text { CMC } \\
\text { suspense orally every day during the study. }\end{array}$ \\
\hline Group II (negative control) & $\begin{array}{l}\text { Given an alloxan } 150 \mathrm{mg} / \mathrm{kgBW} \text { induction } \\
\text { intrapritoneally and CMC } 0.5 \% \text { orally. }\end{array}$ \\
\hline Group III (dose I) & $\begin{array}{l}\text { Hyperglycemic white mice (alloxan-induced) } \\
\text { which were given test preparations of FGF } 800 \\
\mathrm{mg} / \mathrm{kg} \mathrm{BW}+\text { noni fruit extract } 125 \mathrm{mg} / \mathrm{kg} \mathrm{BW} \text {. }\end{array}$ \\
\hline Group IV (dose II) & $\begin{array}{l}\text { Hyperglycemic white mice (alloxan-induced) } \\
\text { given FGF test solution } 800 \mathrm{mg} / \mathrm{kg} \mathrm{BW}+\text { noni } \\
\text { fruit extract } 350 \mathrm{mg} / \mathrm{kg} \mathrm{BW} .\end{array}$ \\
\hline Group V (dose III) & $\begin{array}{l}\text { Hyperglycemic white mice (alloxan-induced) } \\
\text { given FGF test solution } 800 \mathrm{mg} / \mathrm{kg} \mathrm{BW}+ \\
\text { extract of noni fruit } 1000 \mathrm{mg} / \mathrm{kg} \mathrm{BW} \text {. }\end{array}$ \\
\hline $\begin{array}{l}\text { Group VI (administration of } \\
\text { FGF only) }\end{array}$ & $\begin{array}{l}\text { Hyperglycemic white mice (alloxan-induced) } \\
\text { given } 800 \mathrm{mg} / \mathrm{kg} \mathrm{BW} \text { of FGF solution. }\end{array}$ \\
\hline
\end{tabular}

\section{Manufacture of noni fruit ethanol extract}

First, the noni fruit that has been dried mashed with a blender and then soaked with $70 \%$ ethanol, soaked for 6 hours while occasionally stirring then allowed to stand for 24 hours. Then the extract is filtered and the pulp is soaked again with $70 \%$ ethanol and stirred once in a while for 6 hours and allowed to stand for 24 hours, do up to 3 repetitions. All maserat results are collected and then evaporated using an electric evaporator until a thick extract is obtained. ${ }^{10}$

\section{Making FGF suspensions}

The FGF content in egg white flour preparations is made by weighing the egg white flour containing FGF $800 \mathrm{mg} / \mathrm{kg}$ BW, weighing 50 $\mathrm{mg}$ Na.CMC and sprinkled into lumping containing $1 \mathrm{ml}$ of distilled hot water, cover and leave for 15 minutes until a transparent mass is obtained, crushed then input the weighed extract was crushed until homogeneously diluted with distilled water up to $10 \mathrm{ml} .^{11}$

\section{Making suspensions of noni extract (Morinda Citrifolia L.)}

Noni fruit ethanol extract weighed 125, 350, and $1000 \mathrm{mg} / \mathrm{kg}$ BW, respectively. Weighed $50 \mathrm{mg} \mathrm{Na}$ CMC sprinkled into mortars containing $1 \mathrm{ml}$ of hot distilled water, cover and leave for 15 minutes until a transparent period was obtained, crushed then add the extract that had been weighed for a dose of 125,350 , and $1000 \mathrm{mg} / \mathrm{kg} \mathrm{BW}$, crush until homogeneous dilute with distilled water up to $10 \mathrm{ml} .{ }^{11}$

\section{Monitoring blood glucose levels}

Observation of the blood glucose levels of white mice after induction with alloxan was measured by measuring blood glucose levels (ACCUChek) for all groups.

Test preparations were given on day 1 for the next 21 days orally and an examination of blood glucose levels was carried out on days 7, 14, 21.

\section{RESULTS}

Noni obtained was identified at the Andalas University Herbarium. The results of the identification of the species Morinda citrifolia L. were included in the family Rubiaceae. ${ }^{12}$

Noni extract (Morinda citrifolia L.) can be known that the yield of noni extract is $26.68 \%$, theoretically known in the Indonesian Herbal Pharmacopoeia edition 1-year 2008 extract yield not less than $10.9 \%$, this shows the quality of ethanol extract of noni fruit is in good condition.

Phytochemical screening test of noni fruit ethanol extract containing flavonoids, steroids, phenolics and saponins. This phytochemical test is to provide information on the class of chemical content as a parameter of extract quality in relation to pharmacological effects.

The results of the ash content of the noni fruit extract was $0.81 \%$, from the results of the ash content obtained in accordance with the standards stated in the Indonesian Pharmacopoeia edition 1 of 2008 no more than $0.8 \%$.

Figure 1 is the results of average blood sugar levels $(\mathrm{mg} / \mathrm{dL})$ on the $7 \mathrm{th}$, 14th, and 21st days, against the normal and negative control groups, groups III, IV, V, and VI.

Table 2 that is explain from the results of examination of blood glucose levels on day 7 , obtained an average of glucose This shows that the induction of alloxan can increase the blood glucose levels of male white mice. Whereas in the normal

Control group which is a reference to normal blood glucose levels showed that blood glucose levels were stable in the normal range. After administering the test preparations in diabetic mice, the average blood 
glucose levels for the group I dose, dose II, dose III, and FGF alone on the $7^{\text {th }}$ day decreased.

At dose III, the greatest decrease in average blood glucose level of mice was seen, especially on the 21 st day observation $(p<0.05)$. From the diagram above shows the ability of FGF and ethanol extract of noni can inhibit the rise in blood glucose levels of mice and can reduce blood glucose levels in diabetes mice.

At the dose of $350 \mathrm{mg} / \mathrm{dl}$ the decrease was $138.8 \mathrm{mg} / \mathrm{dL}$, and observations on the 14th and 21 st days also showed a decrease in blood glucose levels respectively $124.1 \mathrm{mg} / \mathrm{dL}$ and $104.4 \mathrm{mg} / \mathrm{dL}$. If calculated as a percentage, there was a decrease of $34.51 \%$ and $44.9 \%$, respectively. Group giving by FGF alone which was also a comparison saw decreases on days 7, 14 and 21 respectively 174; 167 and $163 \mathrm{mg} / \mathrm{dL}$. And if it is calculated as a percentage on observation day $7 ; 14$ and 21 results are obtained in a sequence of $9.61 ; 12.33$ and $13.36 \%$.

From Figure 2 the results of the average blood glucose level, the largest percentage reduction was at a dose of $1000 \mathrm{mg} / \mathrm{kg}$ BW on the 21st day observation of $44.90 \%$. The percentage reduction in the group that was only given FGF $800 \mathrm{mg} / \mathrm{kg}$ BW on the 21st day observation indicated the smallest percentage compared to the dose group 125, 350, and 1000 $\mathrm{mg} / \mathrm{kg}$ BW which was equal to $13.56 \%$.

This is due to doses of 125,350 , and $1000 \mathrm{mg} / \mathrm{kg}$ BW of noni fruit is a dose combined with FGF $800 \mathrm{mg} / \mathrm{kg}$ BW. In noni fruit ethanol extract there are active compounds of amino acids (glutamic acid, aspartic acid, isoleucine), flavonoids, and xeronins that are able to work synergistically with FGF in reducing blood glucose levels, while the comparison group which is only given FGF works alone without any help from other compounds such as amino acids, flavonoids, xeronin in reducing blood glucose levels in diabetes mice.

Based on the above results, it shows that the higher dosage dosage given, gives the potential to decrease blood glucose levels which are higher at dose III and the longer the observation time also shows the higher potential on day 21 .

The results of statistical tests conducted with one-way ANOVA on day 7 , seen a significant difference between the 3 variations of the dose and comparison of the decrease in blood glucose levels of diabetes mice where $p<0.05$. On the $14^{\text {th }}$ and $21^{\text {st }}$ days which were tested statistically separately with one-way ANOVA, also gave significant results where $p<0.05$.

After a two-way ANOVA statistical test on the 7th day, 14, 21, a significant result $(p<0.05)$ was seen in the group and time, which means that there was an influence of the duration of observation and dosage variations during the administration of the test preparation ie fruit ethanol extract Noni and FGF to decrease blood glucose levels.

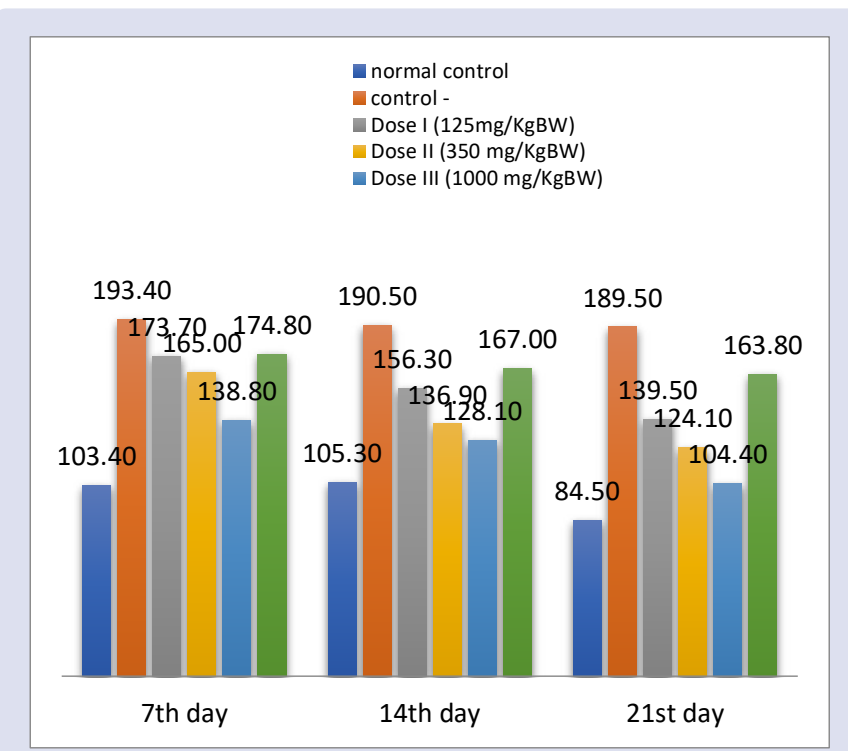

Figure 1: Diagram of the average blood glucose levels for 21 days of observation.

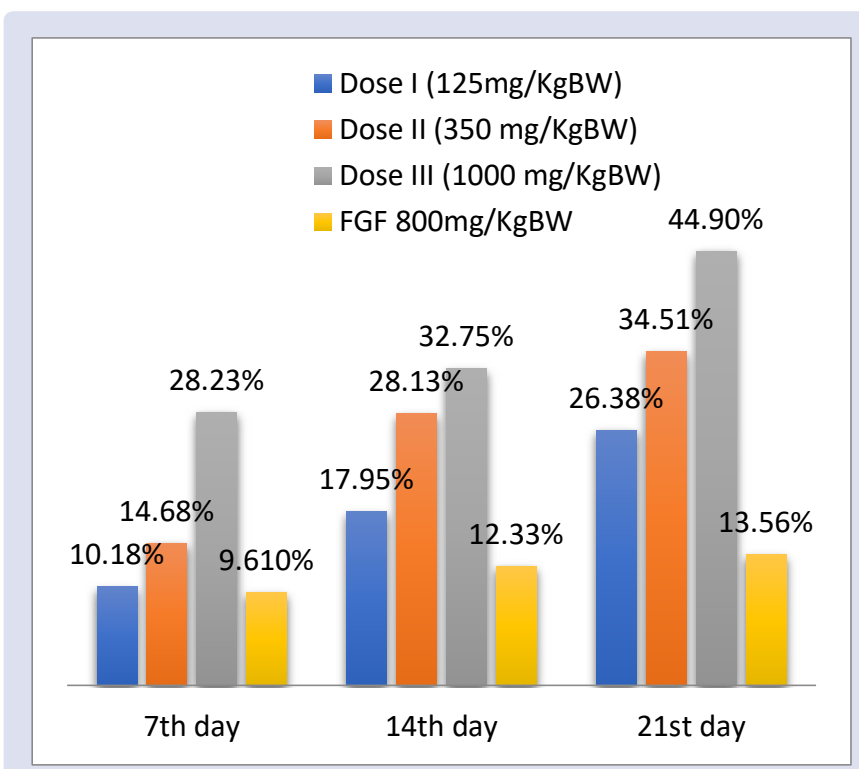

Figure 2: Diagram of percentage decrease in blood glucose level of the test preparation group.

Table 2: Average decrease in blood glucose $(\mathrm{mg} / \mathrm{dL})$ and percentage of decrease in blood glucose in contrast compared to negative controls at the same time.

\begin{tabular}{|c|c|c|c|c|c|c|}
\hline \multirow[b]{3}{*}{ Dose } & \multicolumn{6}{|c|}{ Average blood glucose levels $(\mathrm{mg} / \mathrm{dL}) \pm \mathrm{SD}$ and percentage decrease in blood glucose $(\%) \mathrm{N}=10$} \\
\hline & \multicolumn{2}{|l|}{$7^{\text {th }}$ day } & \multicolumn{2}{|l|}{$14^{\text {th }}$ day } & \multicolumn{2}{|l|}{$21^{\text {st }}$ day } \\
\hline & Average & Percentage (\%) & Average & Percentage (\%) & Average & Percentage (\%) \\
\hline Normal control & $103.40 \pm 90$ & & $105.30 \pm 90$ & & $106,10 \pm 90$ & \\
\hline Negative control & $193.40 \pm 50$ & - & $190.50 \pm 90$ & - & $189.50 \pm 90$ & - \\
\hline $125 \mathrm{mg} / \mathrm{kg} \mathrm{BW}$ & $173.70 \pm 80$ & $10.18 \%$ & $156.30 \pm 80$ & $17.95 \%$ & $139.50 \pm 80$ & $26.38 \%$ \\
\hline $350 \mathrm{mg} / \mathrm{kg} \mathrm{BW}$ & $165.00 \pm 50$ & $14.68 \%$ & $136.90 \pm 70$ & $28.13 \%$ & $124.10 \pm 50$ & $34.51 \%$ \\
\hline $1000 \mathrm{mg} / \mathrm{kg}$ BW & $138.80 \pm 40$ & $28.23 \%$ & $128.10 \pm 70$ & $32.75 \%$ & $104.40 \pm 90$ & $44.90 \%$ \\
\hline FGF $800 \mathrm{mg} / \mathrm{kg} \mathrm{BW}$ & $174.80 \pm 90$ & $9.61 \%$ & $167.00 \pm 50$ & $12.33 \%$ & $163.80 \pm 10$ & $13.56 \%$ \\
\hline
\end{tabular}




\section{CONCLUSION}

Based on the results of the study the effect of ethanol extract of Morinda citrifolia $\mathrm{L}$. on the blood glucose levels of male white mice, the conclusion is: Giving FGF ( $800 \mathrm{mg} / \mathrm{KgBB})$ with noni extract with 3 variations of doses $(125,350,1000 \mathrm{mg} / \mathrm{Kg} \mathrm{BW}))$ can significantly reduce blood glucose levels in diabetic white male mice $(p<0.05)$

Giving dosage test dosages 1, 2 and 3 over the length of time of observation showed the percentage decrease in blood glucose levels seen at dose 3 , with a percentage reduction of $44.90 \%$ on the 21 st day.

Giving 3 variations of the combined dose with FGF compared to FGF alone, seen the potential for a decrease in glucose levels the smallest effect.

\section{ACKNOWLEDGMENTS}

This research was funded by: ANDALAS UNIVERSITY in accordance with Research Contract No: T / 16 / UN. 16.17 / PP.0K - KRP1GB / LPPM / 2019 Fiscal Year 2019.

\section{THE ROLE OF THE WRITER}

The writing of this journal was assisted by several writers, each of whom had the following tasks: Yulia Rahmawati helped complete the research, Nessa edited and compiled the article, Dwisari Dillasamolla and Yulia Rahmawati translated into English and Surya Dharma was responsible for setting the final completion of the article until it was published.

\section{CONFLICTS OF INTEREST}

There were no differences in opinion between authors during the preparation of this article.

\section{REFERENCES}

1. Dharma S. Practical Textbook for Pathophysiology, Pharmacology \& Pharmacotherapy. Yogyakarta: Gre Publishing. 2016.

2. Wild S, Roglic G, Green A, Sicree R, King H. Global prevalence of diabetes: Estimates for the year 2000 and projections for 2030. Diabetes Care. 2014;27(5):1047-53.

3. Yi P, Park JS, Melton DA. Betatrophin: A hormone that controls pancreatic cell proliferation cell. Cell Elsevier. 2013;153:12.

4. Thisse B, Thisse C. Functions and regulations of fibroblast growth factor signaling during embryonic development. Development Biology. 2005;287:390402.

5. Matikainen N. Fibroblast growth factor 21 is a regulator of energy metabolism in the liver and adipose tissue. Nutrition in the prevention and treatment of abdominal obesity. Elsevier Inc.

6. Chunhieng MT. Developpent de nouveaux aliments sante tropicale: application a la noix du Bre sil Bertholettia excelsa et au fruit de Cambodge Morinda citrifolia. Ph.D. thesis, INPL, France.

7. Sridevi N, Sasikumar CS, Cherian KM. Morinda citrifolia (Noni)-a detail review. Int J Univers Pharm Bio Sci. 2012;2(6):494-509.

8. Heinicke RM. The pharmacologically active ingredient of Noni. Excerpts from pacific tropical botanical garden Bulletin. 1985;15(1).

9. Zega, Victorson L, Pemsi M. Wowo, Christi Mambo. Tests of some Non (Morinda citrifolia L.) extracts against blood glucose levels in wistar rats (Rattus norvegicus) induced by aloxan. E-Biomedical Journal (Ebm). 2016;4:2.

10. Anwar K, Sudarsono, Agung EN. Activity of reducing blood glucose levels of non extract (Morinda Citrifolia L.) in stretozotosin-induced mice. Prosiding seminar nasional \& workshop "Perkembangan Sains Farmasi \&Klinis. 2015;225-3.

11. Anwar E. Excipients in pharmaceutical preparations. Jakarta: PT. Dian Rakyat. 2012.

12. Dewi IP, Dharma S, Marlina. Effects of fibroblast growth factor (FGF) from fertilized chicken eggs on blood glucose levels of Hyperglycemic mice. Journal of Pharmaceutical \& Clinical Science. 2006;3(1):1-5, 2442-5435.

\section{GRAPHICAL ABSTRACT}
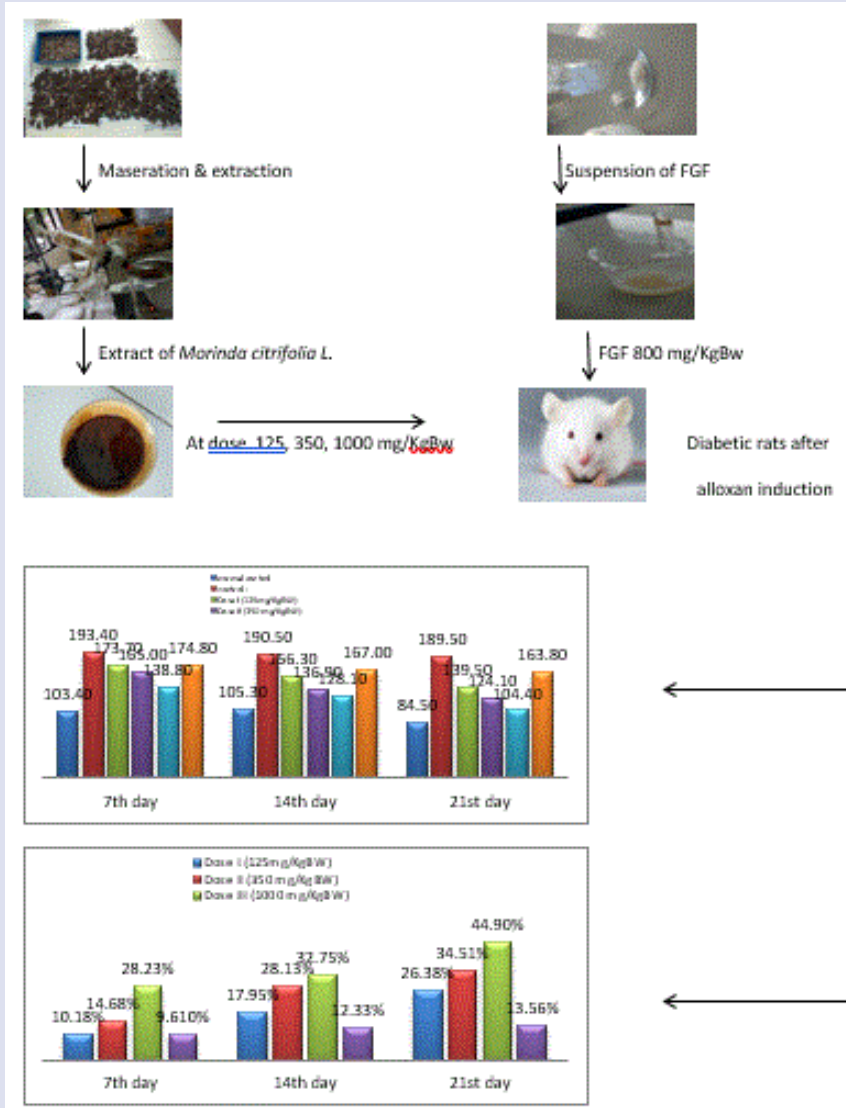

alloxan induction 


\section{SUMMARY}

Noni extract (Morinda citrifolia L.) can be known that the yield of noni extract is $26.68 \%$. FGF requires amino acids in regenerating pancreatic $\beta$ cells, where the amino acids expected from noni fruit can provide a signal response in regenerating pancreatic $\beta$ cells. In addition, the active substances contained in noni fruit namely xeronine and flavonoid alkaloids can function to reduce blood glucose levels at diabetic rats after given $150 \mathrm{mg} / \mathrm{kgBw}$ alloxan. Giving FGF (800 mg / KgBB) with noni extract with 3 variations of doses $(125,350,1000 \mathrm{mg} / \mathrm{Kg} \mathrm{BW})$ can significantly reduce blood glucose levels in diabetic white male mice $(p<0.05)$. Giving dosage test dosages 1, 2 and 3 over the length of time of observation showed the percentage decrease in blood glucose levels seen at dose 3 , with a percentage reduction of $44.90 \%$ on the 21 st day. Giving 3 variations of the combined dose with FGF compared to FGF alone, seen the potential for a decrease in glucose levels the smallest effect.

\section{ABOUT AUTHORS}

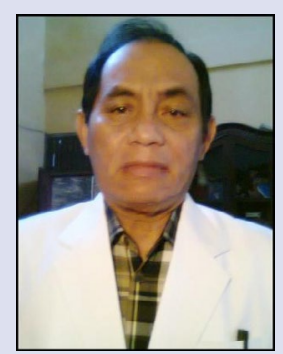

Name: Prof.Dr.Surya Dharma, MS, Apt

Occupation: The lecturer Pharmacy at Andalas University since 1987

Birth/Palace: February 4, 1954/ Bukittinggi

Education:

1. Strata -1 (Andalas University) Padang, 1973

2. Strata-2 (Bandung technology Institute) bandung, 1986

3. Strata 3 (Andalas University) Padang ,2010

Expert: Research in Pharmacology especially on natural drugs

Home Address: Jl. Manga Raya no.67 Perumnas Balimbing Padang

Outcome: Research and writing books

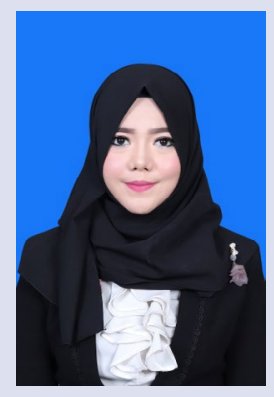

Yulia Rahmawati S.Farm, born in Bangkinang on July 4, 1998, completed her bachelor of pharmacy at STIFI Perimtis Padang in 2019 with a study period of 3 years and 9 month. When I finising my study, I was an assistant lecture for practicum in pharmacology, pharmacy botany, basic chemistry.

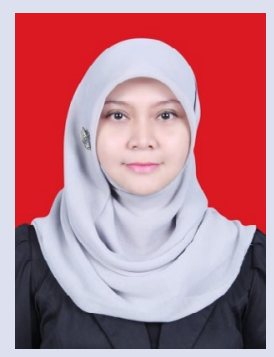

Nessa S. Farm, M.Biomed, born on February 15, 1991, Magister of biomedical science university of indonesia. Working as a lecture at STIFI Perintis Padang. Structural position as chairman of the GKM Pharmacist at STIFI Perintis Padang.

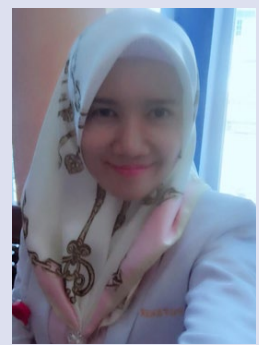

Dwisari Dillasamolla, M.Farm. Apt, currently as lecturer functional position at the Faculty of Pharmacy, Andalas University in 2011. The research and expertise are in Pharmaco-. Immunology Currently working as lecturer Pharmaco-immunology and Clinical Pharmacy of faculty of Pharmacy, Andalas University.

Cite this article: Dharma S, Rahmawati Y, Nessa, Dillasamolla S. Effect of Fibroblast Growth Factor Combination with Ethanol Extract of Morinda citrifolia L. on Blood Glucose levels.Pharmacog J. 2019;11(6)Suppl:1558-62. 